\title{
IDENTIFIKASI FAKTOR-FAKTOR YANG MEMENGARUHI KEBERHASILAN USAHA KOPI JANTAN TORAJA (STUDI KASUS PADA UMKM KOPI 1000 NURHIDAYAH)
}

\author{
Dwi Prasetyawati Thana1), Gidion Aryo Nugraha Pongdatu2), \\ Agustinus Mantong ${ }^{3)}$, dan Hariadi ${ }^{4}$ ) \\ 1)Program Studi Agribisnis, Fakultas Pertanian, Universitas Kristen Indonesia Toraja \\ 2) Program Studi Teknik Informatika, Fakultas Teknik, Universitas Kristen Indonesia Toraja \\ 3)Program Studi Manajemen, Fakultas Ekonomi, Universitas Kristen Indonesia Toraja \\ Kantor Pusat UKI Toraja Jl. Nusantara No. 12 Makale, Indonesia \\ 4)Dinas Pertanian Kabupaten Tana Toraja \\ Kamali Pentalluan, Makale, Kabupaten Tana Toraja, Sulawesi Selatan 91811, Indonesia \\ e-mail: 1)dwipratha01@ukitoraja.ac.id
}

(Diterima 11 Desember 2020 / Revisi 26 Januari 2021 / Disetujui 2 Februari 2021)

\begin{abstract}
A source of income for farmers would be 'Kopi Jantan Toraja' (Peaberry coffee). The growing demand due to changes in the lifestyles of people makes today's coffee more popular. 'Kopi Jantan Toraja' is one of the interesting business options to be produced to boost the farmers' economy. This study aims to define and evaluate the internal and external factors of the "Kopi Jantan Toraja" company in the hope that the internal conditions examined can enable farmers to explore the strengths and weaknesses as well as the opportunities or challenges and threats to be addressed in the company. Internal and external environmental analysis is the type of data collection and analysis used in this study. IFE and EFE in the early phases (Internal and External Factor Evaluation). In the next step, the status of the "Kopi Jantan Toraja" company was calculated by the IE Matrix analysis method. 19 (nineteen) internal factors (8 strengths and 11 weaknesses) and 14 (fourteen) external factors were seen in the IFE and EFE study (8 opportunities and 6 threats). Based on the IE matrix, UMKM Kopi 1000 Nurhidayah's "Kopi Jantan Toraja" company is in a position to keep and sustain, suggesting that a viable approach used by UMKM Kopi 1000 Nurhidayah is market penetration and product growth strategy.
\end{abstract}

Keywords: EFE, IFE, kopi Jantan toraja, peaberry coffee, triumph

\begin{abstract}
ABSTRAK
Kopi jantan akan menjadi sumber pendapatan petani kopi. Permintaan yang makin meningkat dikarenakan perubahan gaya hidup masyarakat menjadikan kopi makin populer saat ini. Kopi jantan menjadi salah satu pilihan usaha yang menarik untuk dikembangkan agar mampu memperbaiki ekonomi petani. Penelitian ini bertujuan untuk mengidentifikasi dan menganalisis faktor internal dan eksternal usaha kopi jantan dengan harapan bahwa kondisi internal yang telah dianalisis dapat membantu petani untuk menggali kekuatan dan kelemahan serta peluang atau tantangan dan ancaman usaha yang dijalankan agar bisa dibenahi sehingga usaha kopi jantan bisa memberikan hasil yang lebih baik. Selain itu, faktor internal dan eksternal ini juga dapat menjadi panduan bagi UMKM Kopi 1000 Nurhidayah untuk merancangkan strategi terbaik untuk mendorong keberhasilan usaha kopi jantan yang dijalankan. Metode pengolahan dan analisis data yang digunakan dalam penelitian ini adalah analisis lingkungan internal dan eksternal. Pada tahap awal digunakan matriks IFE (Internal Faktor Evaluation) dan EFE (Eksternal Faktor Evaluation). Pada tahap selanjutnya digunakan alat analisis Matriks IE. Matriks IE digunakan untuk menentukan posisi usaha kopi jantan. Analisis IFE dan EFE menunjukkan adanya 19 (sembilan belas) faktor internal (8 kekuatan dan 11 kelemahan) dan 14 (empat belas) faktor eksternal (8 peluang dan 6 ancaman). Berdasarkan matriks IE, usaha kopi jantan UMKM Kopi 1000 Nurhidayah berada pada posisi dimana pihak UMKM harus bertahan (hold and maintain) yang menunjukkan bahwa strategi yang layak digunakan oleh UMKM Kopi 1000 Nurhidayah adalah strategi untuk menjangkau pasar yang lebih luas (penetrasi pasar) dan mengembangkan.
\end{abstract}

Kata kunci: EFE, IFE, keberhasilan, kopi jantan Toraja 


\section{PENDAHULUAN}

Kopi memiliki prospek yang menjanjikan untuk dibudidayakan melihat semakin luasnya pasar dan semakin meningkatnya permintaan terhadap kopi ditunjang dengan banyaknya pihak yang memulai usaha dalam penyajian minuman penyegar kopi di kedai yang tersebar hampir di seluruh Indonesia bahkan di pedesaan sekalipun (Purnama, 2014). Kopi semakin populer di kalangan masyarakat khususnya dipengaruhi oleh gaya hidup yang berubah. Masyarakat lebih banyak menghabiskan waktu menikmati kopi di luar rumah bahkan bercengkrama dengan sahabat hanya untuk sekedar menikmati segelas kopi sembari bertukar pikiran untuk menghasilkan suatu karya.

Salah satu kopi yang menjadi favorit masyarakat adalah kopi arabika dari Toraja. Menurut Marampa (2016), Kopi Toraja merupakan salah satu jenis kopi dari Indonesia yang memiliki cita rasa dan daya saing internasional. Kopi arabika Toraja memiliki cita rasa dan aroma khas yang tidak dimiliki oleh kopi lain karena iklim yang dimiliki oleh Toraja sendiri dan ketinggian tempat dari Toraja yang berbeda dengan daerah lainnya. Hal ini juga diungkapkan oleh Tanan (2012) bahwa kopi Toraja khususnya kopi arabika yang kemudian dikenal sebagai kopi specialty Toraja (Toraja Arabica Coffee), telah dikonsumsi oleh berbagai bangsa di dunia. Hal ini dimungkinkan karena rasa dan aromanya yang khas, yang tidak diperoleh dari kopi lain termasuk kopi specialty dari daerah lain di Indonesia. Karena kekhasan ini, ada beberapa petani yang melihat adanya peluang untuk menjual biji kopi hasil sortasi yang disebut dengan kopi jantan (di Jawa dikenal dengan nama kopi Lanang). Kopi berbiji satu ini dipercaya memiliki rasa dan aroma yang lebih kuat dibandingkan kopi arabika secara umum. Kopi Jantan merupakan kopi hasil sortasi yang sangat istimewa dimana kopi ini diketahui jika dilakukan pemeriksanaan atau pengecekan secara manual, yaitu biji kopi harus dipilih terlebih dahulu kemudian daging buahnya dikupas kemudian bijinya hanya sebuah saja atau berbiji satu. Ciri khas dari kopi jantan atau lanang atau peaberry coffee adalah berbiji tunggal yang dihasilkan dari pembuahan yang tidak normal. Ini mungkin terjadi karena tiga faktor utama yaitu kegagalan di salah satu dari dua ovula di ovarium yang akan dibuahi dan menghasilkan benih, gagal dalam perkembangan endosperma dan ketidakcocokan kedua orang tua selama penyerbukan (Yilma, 2020). Jumlah kopi jantan sangat terbatas pada satu pohon, yaitu hanya sekitar 3-5 persen saja dari satu pohon, sehingga hal inilah yang menjadi salah satu penyebab kopi jantan bernilai ekonomis tinggi karena cukup sulit untuk memperolehnya dalam jumlah yang banyak (Dien, 2012). Kopi Jantan Toraja merupakan salah satu produk kopi unggulan yang didukung secara langsung oleh menteri pertanian ketika berkunjung ke Toraja beberapa waktu yang lalu. Pada segi ekonomi, kopi jantan sangat menjanjikan bagi para petani. Dimana harga jual kopi jantan saat ini (berdasarkan informasi dari salah satu petani kopi jantan Toraja, Kolumbanus, roasted bean 150 gr) seharga Rp50.000,00 atau sekitar Rp300.000,00Rp350.000,00 per kilogram roasted bean kopi jantan Toraja jenis Arabika.

Hal inilah yang menjadi alasan petani memanfaatkan peluang tersebut untuk memperbaiki ekonomi mereka. Karena memperoleh biji kopi tersebut agak sulit (disortasi secara manual), harga biji kopi jantan lebih tinggi dibandingkan kopi arabika secara umum.

UMKM Kopi 1000 Nurhidayah adalah salah satu unit usaha kopi yang terletak di Gandang Batu Sillanan, Tana Toraja yang cukup dikenal banyak orang. Selain kopi jantan yang menjadi produk unggulan, ada beberapa varian biji kopi juga yang diusahakan oleh UMKM Kopi 1000 Nurhidayah. Mengingat kopi jantan hanyalah kopi hasil sortasi, maka muncul pertanyaan akankah kopi jantan ini bertahan menjadi salah satu produk unggulan UMKM? Sementara harga dari kopi jantan sendiri lebih mahal dibandingkan kopi arabika pada umumnya.

Berhasilnya suatu usaha tentu saja dipengaruhi oleh beberapa faktor, baik itu faktor internal maupun faktor eksternal. Faktor internal adalah hal-hal yang terkait dengan kekuatan dan kelemahan dari perusahaan dan faktor eksternal adalah faktor-faktor dari luar perusahaan yang terkait dengan ancaman dan peluang bagi perusahaan. Faktor internal dan eksternal ini tentu saja harus sesuai dengan kondisi internal dari perusahaan itu sendiri. 
Berdasarkan uraian di atas, maka rumusan masalah dari penelitian ini adalah:

1. Bagaimana kondisi internal usaha kopi jantan Toraja pada UMKM Kopi 1000 Nurhidayah?

2. Bagaimana kondisi eksternal usaha kopi jantan Toraja pada UMKM Kopi 1000 Nurhidayah?

3. Langkah apa yang sebaiknya dilakukan UMKM Kopi 1000 Nurhidayah agar mendorong keberhasilan usaha kopi jantan Toraja berdasarkan kondisi internal dan eksternalnya?

Adapun tujuan dari penelitian ini adalah untuk mengidentifikasi dan menganalisis faktor internal dan eksternal usaha kopi jantan pada UMKM Kopi 1000 Nurhidayah. Penelitian ini penting untuk dilakukan dengan harapan bahwa kondisi internal yang telah dianalisis dapat membantu petani untuk menggali kekuatan dan kelemahan serta peluang atau tantangan dan ancaman usaha yang dijalankan agar bisa dibenahi sehingga usaha kopi jantan bisa memberikan hasil yang lebih baik. Faktor internal dan eksternal ini juga dapat menjadi panduan bagi UMKM Kopi 1000 Nurhidayah untuk merancangkan strategi terbaik untuk mendorong keberhasilan usaha kopi jantan yang dijalankan.

\section{METODE}

\section{LOKASI PENELITIAN}

Penelitian ini dilakukan pada UMKM Kopi 1000 Nurhidayah di Pedallean Dusun Malaleo Lembang Gandang Batu Sillanan Kabupaten Tana Toraja Sulawesi Selatan. Penelitian ini secara keseluruhan dilakukan selama \pm 3 bulan, yakni dari bulan September sampai November 2020.

\section{METODE ANALISIS DATA}

Metode pengolahan dan analisis data yang digunakan dalam penelitian ini adalah analisis lingkungan internal dan eksternal. Pada tahap awal digunakan matriks Internal Factor Evaluation (IFE) dan Eksternal Factor Evaluation (EFE). Selanjutnya, dilakukan pembobotan pada faktor internal dan eksternal yang selanjutnya akan membantu menggambarkan matriks IE. Pemberian bobot (weight) antara 0 (tidak penting) sampai 1 (sangat penting) untuk setiap faktor. Pembobotan tingkat relatif kepentingan mengacu kepada visi-misi perusahaan (industrial based). Bobot akumulasi strength \& weakness harus berjumlah 1 . Pemberian rating antara 1 (sangat lemah) sampai 4 (sangat kuat). Pemberian rating berdasarkan company based untuk strength adalah 3 atau 4 sedangkan untuk weakness adalah 1 atau 2. Setelah itu, dilakukan perhitungan nilai terbobot (weighted score): bobot $\mathrm{x}$ rating. Menjumlahkan weighted score akumulasi strength \& weakness untuk analisa IFE. Untuk pembobotan pada EFE sama halnya dengan pemberian bobot dan rating pada IFE (David, 2011 dalam Leliga, 2019). Pada tahap selanjutnya digunakan alat analisis Matriks Internal - Eksternal (IE) yang digunakan untuk menentukan posisi usaha kopi jantan berdasarkan hasil perhitungan bobot dan rating pada IFE dan EFE.

\section{METODE PENGUMPULAN DATA}

Pengumpulan data dalam penelitian ini dilakukan melalui 3 (tiga) cara, yaitu (a) studi kepustakaan dilakukaan untuk memperoleh data sekunder serta untuk mendapatkan kajian dasar teoritis yang relevan dengan masalah yang diteliti, (b) Studi lapangan (observasi) dilakukan untuk mengumpulkan data primer melalui penyebaran kuesioner untuk mengetahui faktor internal dan eksternal usaha kopi jantan Toraja dalam melakukan kegiatan pemasaran kemudian hasilnya akan dicatat dan diolah atau dianalisis, serta (c) Wawancara Mendalam dan FGD dilakukan dengan tanya-jawab secara langsung dengan narasumber terpilih agar memperoleh informasi yang lebih dalam yang tidak terakomodasi dari kuesioner. Data yang diperoleh dari hasil wawancara dan FGD digunakan dalam keseluruhan analisis, khususnya pada pembahasan masing-masing faktor internal dan eksternal dan kaitannya dengan keberhasilan usaha Kopi Jantan yang dijalankan oleh UMKM Kopi 1000 Nurhidayah.

\section{TEKNIK PENGAMBILAN SAMPEL}

Sampel dalam penelitian ini dinamakan narasumber. Pemilihan narasumber dalam penelitian ini menggunakan metode bola salju (snowball sampling) yaitu teknik pengambilan sampel yang pada awalnya sedikit lama-lama menjadi besar. Sampel sumber data dimulai dari narasumber kunci (key informant) sebagai pelaku yang mempengaruhi pengambilan kebijakan pada 
UMKM Kopi 1000 Nurhidayah, kemudian narasumber kunci akan mengarahkan atau menunjuk narasumber lainnya yang juga dianggap banyak mengetahui dan menguasai informasi terkait masalah yang diteliti. Narasumber yang digunakan dalam penelitian ini berjumlah 8 (delapan) orang. Para narasumber inilah yang akan menjadi sumber informasi terkait faktor internal dan eksternal dari Kopi Jantan Toraja. Selanjutnya, dilakukan wawancara mendalam dan FGD untuk memperjelas tiap-tiap faktor yang diinformasikan.

\section{HASIL DAN PEMBAHASAN}

\section{IDENTITAS NARASUMBER}

Identitas narasumber ini menjelaskan kondisi (keadaan) serta status dari narasumber tersebut. Pada pelaksanaan penelitian, narasumber sangat membantu dan memudahkan peneliti untuk mendapatkan informasi - informasi terkait tujuan penelitian. Narasumber dalam penelitian ini merupakan orang-orang yang mempunyai latar belakang sebagai pelaku yang mempengaruhi pengambilan keputusan atau kebijakan pada UMKM Kopi 100 Nurhidayah.

Berdasarkan hasil wawancara dengan menggunakan kuesioner pada penelitian yang dilaksanakan di UMKM Kopi 1000 Nurhidayah maka data narasumber yang diperoleh dapat dilihat pada Tabel 1.

Tabel 1 menunjukkan nama-nama Narasumber yang terkait langsung dengan UMKM Kopi 1000 Nurhidayah yang terdiri dari delapan orang yaitu Bapak Hariadi sebagai penyuluh pertanian yang mendampingi berjalannya UMKM Kopi 1000 Nurhidayah dan juga merupakan Narasumber kunci dalam penelitian ini, Bapak Laurensius Palinoan sebagai penyuluh pertanian yang juga mendampingi UMKM Kopi 1000 Nurhidayah, Ibu Nurhidayah sebagai ketua UMKM Kopi 1000 Nurhidayah sekaligus pencetus penjualan kopi jantan Toraja, Bapak Albert Otto sebagai ketua Koperasi Petani Kopi Toraja "Kopinta", Bapak Daud Sinae selaku ketua kelompok tani Tallubangan, Ibu Rosita P., Bapak Rawe dan Ibu Agustina Tappi Sammane sebagai penyuluh pertanian yang menjadi rekan Bapak Hariadi dalam membina, mengarahkan dan mendampingi petani UMKM Kopi 1000 Nurhidayah. Para narasumber inilah yang membantu peneliti dalam mengisi kuesioner, FGD dan juga wawancara.

\section{ANALISIS LINGKUNGAN INTERNAL DAN EKSTERNAL}

Analisis internal adalah analisis mengenai kekuatan dan kelemahan yang dimiliki oleh perusahaan. Kekuatan yang dimiliki oleh UMKM Kopi 1000 Nurhidayah, yaitu:

a. Kualitas produk baik (lokalita diperkuat budaya)

Kopi jantan yang dihasilkan oleh UMKM Kopi 1000 Nurhidayah adalah kopi specialty dengan hasil penilaian sebesar 86. Selain itu, biji kopi yang dihasilkan adalah lokalita dan diperkuat dengan budaya yang dimiliki. Hal ini tentu saja menjadi pegangan yang kuat bagi UMKM untuk

Tabel 1. Identitas Narasumber UMKM Kopi 1000 Nurhidayah

\begin{tabular}{|c|c|c|c|c|c|c|}
\hline \multirow{3}{*}{ No } & \multicolumn{6}{|c|}{ Identitas } \\
\hline & \multirow[t]{2}{*}{ Nama } & \multirow{2}{*}{$\begin{array}{c}\text { Usia } \\
\text { (Tahun) }\end{array}$} & \multirow[t]{2}{*}{ Pendidikan } & \multirow[t]{2}{*}{ Jabatan } & \multicolumn{2}{|c|}{$\begin{array}{c}\text { Lama } \\
\text { Bekerja }\end{array}$} \\
\hline & & & & & Thn & Bln \\
\hline 1. & Hariadi & 40 & S1 & Penyuluh Pertanian & 4 & - \\
\hline 2. & Laurensius Palinoan & 49 & S1 & Penyuluh Pertanian & 12 & 9 \\
\hline 3. & Nurhidayah & 46 & SLTA & $\begin{array}{l}\text { Ketua UMKM Kopi } 1000 \\
\text { Nurhidayah }\end{array}$ & 4 & 3 \\
\hline 4. & Albert Otto & 46 & SLTA & $\begin{array}{l}\text { Ketua Koperasi Petani Kopi } \\
\text { Toraja "Kopinta" }\end{array}$ & 1 & 5 \\
\hline 5. & Daud Sinae & 54 & SLTA & Ketua Klp. Tani Tallubangan & 25 & - \\
\hline 6. & Rosita P. & 42 & S1 & Penyuluh Pertanian & 12 & 9 \\
\hline 7. & Rawe & 52 & $\mathrm{~S} 1$ & Penyuluh Pertanian & 4 & - \\
\hline 8. & $\begin{array}{l}\text { Agustina Tappi } \\
\text { Sammane }\end{array}$ & 42 & $\mathrm{~S} 1$ & Penyuluh Pertanian & 3 & - \\
\hline
\end{tabular}

Sumber: Data Primer Setelah Diolah, 2020 
bisa menentukan harga yang tepat untuk kopi yang dihasilkan karena cita rasa dan aroma yang dimiliki cukup khas dan juga berbeda dengan kopi yang ada di daerah lain. Selain itu, konsumen juga akan merasa puas dengan produk kopi yang dihasilkan. Hal ini juga diungkapkan oleh Mu'tashim (2019) bahwa kualitas produk berpengaruh signifikan terhadap kepuasan konsumen pada seluruh responden.

b. Pelaku utama industri adalah petani langsung UMKM Kopi 1000 Nurhidayah merupakan salah satu unit produksi kopi yang memberdayakan petani kopi lokal dimana UMKM ini berusaha mengarahkan para petaninya untuk menjadi industri hulu - hilir. Menurut salah satu narasumber (Hariadi), ketika pelaku industri adalah petani itu sendiri, maka skill petani bisa bertambah dengan adanya pelatihanpelatihan (khususnya terkait pengelolaan usaha kopi) sehingga manfaat yang diperoleh dapat dirasakan langsung oleh petani. Hal ini dapat memicu petani untuk selalu ingin menghasilkan dan memberikan produk yang terbaik bagi konsumen sehingga apa yang diinginkan oleh petani dapat tercapai dengan lebih baik. Hasil penelitian Nasruddin (2015), mengatakan bahwa tingkat kewirausahaan pelaku agribisnis secara umum (tanpa membedakan subsistem dan komoditas) menunjukkan bahwa melalui uji pengenalan diri cenderung masuk kategori kuat (55\%) dan sedang (45\%). Persentase tinggi ( $>50 \%)$ dalam kategori kuat dimiliki oleh para pelaku pada subsistem luar usahatani (off-farm) dan sisanya oleh para pelaku pada subsistem onfarm (petani). Hal inilah yang menjadi kekuatan bagi petani pada UMKM Kopi 1000 Nurhidayah bahwa hasil penelitian Nasruddin dapat terbantahkan dengan makin terpicunya petani untuk menjadi pelaku utama industri.

c. Industri hulu-hilir dan integrasi lokalita Para petani diarahkan menjadi industri kopi yang dapat melakukan budidaya, pasca panen sampai menghasilkan kopi dalam bentuk serapan pasar baik greenbean, roasted bean dan bubuk kopi dengan kemasan yang baik. Hal ini tidak terlepas dari produk lokalita yang menjadi harapan dari konsumen dan juga produsen, yaitu petani kopi itu sendiri.

d. Industri sudah terbentuk di petani Karena mulai dari awal, petani diarahkan menjadi industri, maka saat ini industri sudah terbentuk di kalangan petani walau belum maksimal. Tetapi hal ini sudah dianggap baik dan bisa menjadi kekuatan karena petani dapat dengan mandiri mampu berusaha untuk menghasilkan biji kopi terbaik.

e. Potensi produksi SDM tersedia

Para petani yang bergabung di UMKM Kopi 1000 Nurhidayah memiliki potensi untuk menghasilkan produksi terbaik berupa biji kopi greenbean yang sesuai dengan standar yang telah ditetapkan. Hal ini dapat berdampak baik bahwa petani dapat memberikan produk yang baik bagi konsumen sehingga konsumen dapat menikmati kopi terbaik dari Toraja khususnya yang dihasilkan oleh UMKM Kopi 1000 Nurhidayah. tentu saja, ini dapat membantu berjalannya usaha kopi jantan Toraja karena akan dicari oleh para konsumennya.

f. Koorporasi petani sudah terbentuk Petani kopi yang ada di Sillanan Gandangbatu bergabung menjadi satu membentuk sebuah badan usaha UMKM Kopi 1000 Nurhidayah yang diketuai oleh ibu Nurhidayah. Dengan adanya korporasi seperti ini, harapannya adalah petani mampu saling bekerjasama untuk memaksimalkan hasil produksi kopi yang mereka miliki. Ini dapat memperkuat kerjasama antarpetani untuk memperoleh produksi yang maksimal dan keuntungan yang maksimal. Sehingga, petani akan selalu berusaha untuk meningkatkan produksi dan juga meningkatkan kualitas biji kopi yang dihasilkan dengan saling bekerjasama.

g. Lokasi cukup strategis

Seperti yang kita ketahui bahwa rasa kopi itu tergantung pada lokasi tempat tumbuhnya. Lokasi UMKM Kopi 1000 Nurhidayah pada umumnya cukup jauh untuk dijangkau. Tetapi, dari sudut pembudidayaan kopi, lokasi ini cukup strategis untuk tumbuh kembangnya tanaman kopi sehingga mampu menghasilkan biji kopi yang khas, baik dari aroma maupun rasa. Menurut Nurleli (2018) dalam Audia 
(2019), bahwa ketinggian lereng gunung yang berkisar $1.000 \mathrm{mdpl}$ cocok untuk pengembangan tanaman kopi. Hal ini tentu saja salah satu faktor yang menjadikan kopi yang dihasilkan berkualitas baik dan menjadikannya kopi specialty.

h. Modal cukup memadai

Modal yang dimiliki oleh UMKM Kopi 1000 juga dapat memberikan hasil produksi berupa biji kopi yang berkualitas sehingga banyak yang tertarik untuk menjadi sumber modal bagi keberlanjutan usaha kopinya. Selain itu, UMKM didampingi oleh para pendamping UMKM (dalam hal ini penyuluh pertanian), secara aktif mencari pasar untuk menjual hasil produksi kopi mereka yang kemudian dijadikan sumber modal untuk kelancaran usaha kopi, khususnya kopi jantan yang menjadi salah satu produk unggulan UMKM kopi 1000 Nurhidayah. Dengan adanya modal yang cukup memadai, juga dapat menunjang tingkat produksi kopi yang dihasilkan oleh UMKM Kopi 1000 Nurhidayah. Berdasarkan hasil regresi pada penelitian Yulanda (2019), modal memiliki nilai signifikansi sebesar 0,012 atau kurang dari 0,05 yang artinya variabel modal berpengaruh secara signifikan pada produksi kopi arabika. Selain itu, koefisien korelasi pada variabel modal bertanda (+) yang berarti semakin tinggi modal maka produksi kopi arabika akan meningkat.

Adapun kelemahan yang dimiliki oleh UMKM Kopi 1000 Nurhidayah adalah sebagai berikut.

a. SDM petani terbatas

Sumber daya petani dianggap terbatas karena banyak hal yang masih perlu dipelajari oleh petani terkait pemeliharaan yang baik bagi tanaman kopi, termasuk pemangkasan, penyiangan, pemupukan dll. Terkadang kebanyakan petani yang masih lalai dalam melakukan kegiatan tersebut karena menurut para petani hal itu (pemangkasan) akan mengurangi produksi kopi. Selain itu, penyiangan dianggap sedikit membuang waktu dimana para petani memiliki banyak kesibukan lain yang harus dilakukan. Hal ini dapat berdampak pada tidak sesuainya target kualitas produk yang diharapkan dengan yang dihasilkan. Jika SDM petani tidak di-upgrade, maka hal ini dapat mempengaruhi berjalannya usaha kopi yang dijalankan karena konsumen hanya akan mencari dan mengonsumsi kopi yang berkualitas baik.

b. Inovasi petani masih kurang bervariasi Pada dasarnya, petani umumnya hanya mengetahui satu jenis pengolahan pascapanen kopi yaitu semiwashed. Sementara, untuk proses pengolahan pascapanen kopi ada beberapa, diantaranya yaitu proses natural, honey, fullwashed, dll. Oleh karena itu, petani perlu meningkatkan inovasi agar biji kopi yang dihasilkan lebih bervariasi dimana saat ini banyak konsumen yang menginginkan biji kopi dengan berbagai varian rasa. Sehingga, kedepannya usaha kopi jantan ini dapat bertahan bahkan berlanjut dan memberikan keuntungan yang maksimal bagi petani.

c. Kerjasama petani belum terintegrasi dengan baik

Kerjasama petani dikatakan belum terintegrasi dengan baik, karena apabila ada suatu kegiatan yang perlu melibatkan semua petani yang ada, terkadang ada beberapa diantaranya yang tidak bisa mengikuti kegiatan tersebut dikarenakan urusan pribadi, misalnya mengikuti kegiatan upacara adat. Walaupun terjalin kerjasama yang baik untuk hal-hal yang lain, tetapi jika ada kegiatan yang mendesak terlebih jika untuk peningkatan SDM petani, maka memang perlu menurunkan keegoisan masing-masing agar visi sebagai industri itu dapat tercapai. Jika masing-masing mementingkan kepentingan pribadi, maka usaha yang sudah dijalankan dengan baik bisa saja berhenti di tengah jalan jika tidak ada kerjasama yang baik untuk kepentingan bersama. Hasil penelitian Nasution (2019) mengatakan bahwa adanya kerjasama antar anggota kelompok dalam kegiatan usahatani padi sawah dapat meningatkan produktivitas padi sawah menjadi lebih besar dibandingkan dengan tidak adanya kerjasama dimana hasil penelitian menunjukkan bahwa yang bekerjasama ada 43 orang $(100 \%)$. Kerjasama yang dimaksud adalah kerjasama dalam kegiatan pencapaian 
hasil produktivitas yang tinggi dan saling bekerjasama dalam pemberian inovasi baru.

d. SOP khusus kopi Jantan Toraja belum ditetapkan dan dibuat

Untuk produksi kopi yang berkualitas dan tidak beragam, maka perlu menyeragamkan semua proses yang berlangsung pada setiap proses produksi kopi. Hal ini bisa terjadi jika SOP khusus kopi jantan telah ditetapkan dan dibuat serta disosialisasikan kepada seluruh petani dan para stakeholder yang berperan dalam UMKM Kopi 1000 Nurhidayah. Winata (2016) dalam penelitiannya mengatakan bahwa Rancangan SOP dibuat secara terstruktur dan terperinci agar dapat digunakan sebagai pedoman, sehingga siapapun yang membaca SOP tersebut akan menjalankan prosedur yang sama dan dapat menghasilkan produk yang sesuai dengan standarisasi. Hal inilah yang juga diinginkan oleh UMKM Kopi 1000 Nurhidayah agar semua produk kopi yang dihasilkan sesuai dengan standar yang diinginkan.

e. Petani masih sangat bergantung pada pendamping

Karena inovasi serta SDM petani masih kurang, maka sebagian besar aktivitas dalam pengembangan usaha kopi digantungkan kepada pendamping. Hal ini tentu saja membuat para pendamping kewalahan karena harus terlibat secara langsung dan mendominasi kegiatan yang dilakukan. Menurut informan kunci, bapak Hariadi, jika petani hanya bergantung kepada pendamping saja, maka hasil yang maksimal tidak bisa diperoleh karena petani tidak bisa produktif jika hanya bergantung kepada pendamping saja. Oleh karena itu, petani perlu untuk meningkatkan SDM-nya serta membangun etos kerja yang baik agar bisa lebih mandiri untuk memberikan hasil yang terbaik. Jika petani bisa mandiri untuk mengembangkan diri sendiri, maka itu bisa memberikan dampak positif, khususnya dari segi kuantitas dan kualitas produksi, dan juga dari segi financial. Hal ini juga ditegaskan oleh Hetharion (2020) bahwa kemandirian kelompok tani merupakan salah satu indikator penting dalam menilai keberhasilan suatu kelompok tani. f. Ketekunan petani belum kuat

Petani yang terlibat pada UMKM Kopi 1000 Nurhidayah terlalu mementingkan kepentingan pribadi (khususnya menghadiri upacara adat). Hal ini menyebabkan para petani tidak sepenuhnya memperhatikan semua proses yang ada dalam budidaya hingga proses pascapanen kopi. Petani belum menjadikan kebun kopi mereka sebagai sesuatu yang harus disayangi dan dipelihara agar mampu memberikan hasil terbaik demi meningkatkan kesejahteraan petani sendiri. Jika demikian, maka jumlah produksi dan kualitas biji kopi yang diharapkan tidak dapat dicapai, sehingga akan menyebabkan ketidakpuasan konsumen dan pada akhirnya minat konsumen terhadap biji kopi jantan yang dihasilkan oleh UMKM Kopi 1000 Nurhidayah.

g. Produktivitas kopi rendah

Karena kurang mendapatkan perhatian dari para petani, maka produktivitas kopi kurang maksimal. Rendahnya produktivitas kopi ini juga disebabkan karena kebanyakan kopi yang tumbuh sudah tua sehingga produktivitasnya juga rendah. Hal ini dapat mempengaruhi tingkat pendapatan petani karena produk yang ditawarkan tidak mampu memenuhi permintaan yang ada. Ini juga diungkapkan oleh Mulyani (2019) dalam penelitiannya bahwa produktivitas itu digunakan sebagai tolok ukur keberhasilan suatu industri pertanian dalam menghasilkan barang dan jasa. Sehingga semakin tinggi perbandinganya, semakin tinggi produk yang dihasilkan, semakin tinggi tingkat produktivitas yang dicapai maka semakin tinggi pula pendapatan yang akan diperoleh masyarakat, dan begitupun sebaliknya, semakin rendah produktivitas kopi maka pendapatan yang diperoleh juga semakin rendah.

h. Sarana produksi terbatas

Sarana produksi yang digunakan pada usaha kopi jantan UMKM Kopi 1000 Nurhidayah masih sangat terbatas, dimana fasilitas penjemuran hanya ada satu yang terpaksa digunakan oleh petani secara bergantian. Selain itu, peralatan yang digunakan juga masih tergolong sederhana. Hal ini dapat mengakibatkan petani tidak bisa memberikan hasil yang 
maksimal dikarenakan fasilitas penjemuran yang harus berpindah-pindah sehingga waktu untuk mengeringkan biji kopi tidak bersamaan. Dimana kejadian ini dapat mempengaruhi tidak bisanya memenuhi permintaan pada waktu yang diinginkan oleh konsumen. Sementara proses agribisnis dapat berjalan dengan baik jika dapat memenuhi $6 \mathrm{t}$, yaitu tepat waktu, tepat tempat, tepat jumlah, tepat mutu, tepat jenis, dan tepat harga (Panjaitan, 2017).

i. Manajemen produksi belum baik

Dalam menjalankan sebuah usaha, yang perlu diperkuat adalah manajemennya agar tujuan yang diinginkan bisa tercapai secara maksimal. Hanya saja manajemen yang ada di UMKM Kopi 1000 Nurhidayah belum berjalan dengan baik, khususnya pada bidang produksi. Sehingga, hal inilah yang menjadi pemicu munculnya kelemahan-kelemahan lainnya misalnya ketekunan petani belum kuat serta produktivitas kopi rendah, dll. Jika manajemen kurang baik maka usaha kopi maka akan memberikan dampak buruk bagi berjalannya usaha kopi jantan.

j. Promosi kurang Kegiatan promosi yang dilakukan masih begitu terbatas, yaitu melalui pameran, festival dan kompetisi-kompetisi. Bentuk promosi ini masih dianggap kurang karena belum menjangkau konsumen secara luas. Jika konsumen terbatas, maka pendapatan petani pun kurang karena terbatasnya permintaan terhadap biji kopi jantan yang dihasilkan. Oleh karena itu, perlu adanya perbaikan di bidang promosi agar jangkauan konsumen makin luas sehingga usaha kopi jantan yang dijalankan dapat berlangsung lama dan memberikan keuntungan yang maksimal.

k. Teknologi dan desain produk masih kurang Teknologi yang digunakan baik pada proses hulu hingga hilir masih sangat kurang. Kurangnya teknologi dapat mempengaruhi kualitas biji kopi yang dihasilkan sehingga perlu adnya peningkatan teknologi pada proses pengolahan hingga pascapanen kopi. Kurangnya teknologi ini juga mempengaruhi tampilan produk dari segi desain kemasan. Dimana kita ketahui bahwa desain kemasan produk juga menentukan daya tarik pembeli atau konsumen terhadap produk yang dihasilkan. Makin tinggi daya tarik pembeli, maka permintaan akan meningkat, dan pendapatan pun akan meningkat. Sehingga hal ini dapat mendorong petani untuk meningkatkan hasil produksi agar mampu memenuhi permintaan yang ada.

Analisis eksternal bertujuan untuk menganalisis peluang dan ancaman yang dimiliki oleh UMKM Kopi 1000 Nurhidayah dalam menjalankan bisnisnya. Peluang yang dimiliki oleh UMKM Kopi 1000 Nurhidayah yaitu:

a. Eduagrowisata kopi

Adanya rencana untuk menjadikan kecamatan Gandangbatu Sillanan sebagai eduagrowisata kopi menjadi peluang besar bagi UMKM Kopi 1000 Nurhidayah untuk mengembangkan usaha dan memberikan hasil produksi terbaik. Selain itu, kesempatan ini juga dapat memicu petani untuk meningkatkan produksi dan kualitas biji kopi yang dihasilkan sehingga bisa menjadi salah satu sarana untuk promosi dimana kesempatan ini dapat menjadi ajang untuk memperkenalkan hasil produksi yang baik ke seluruh dunia sehingga jangkauan konsumen luas.

b. Tempat sinergitas semua pelaku usaha kopi Salah satu peluang juga yang dapat dimanfaatkan adalah Toraja akan menjadi tempat sinergitas semua pelaku usaha kopi. Hal ini dapat dimanfaatkan oleh para petani kopi yang bergabung dengan UMKM Kopi 1000 Nurhidayah untuk meningkatkan kualitas, kuantitas dan harga kopi yang dihasilkan, khususnya kopi jantan.

c. Pemasaran online mendukung

Saat ini, bisnis e-commerce makin meluas dan teknologi informasi juga makin berkembang. Hal ini dapat dimanfaatkan sebagai sarana pemasaran secara online agar menjangkau pasar yang lebih luas. Dengan semakin meluasnya jangkauan pasar, maka peluang untuk mengembangkan bisnis ke arah yang lebih baik akan terbuka lebar. Selain itu, hal ini juga tentu saja berpengaruh terhadap pendapatan petani kopi jantan Toraja di Sillanan.

d. Mandiri modal dan partnership menjadi pilihan

Untuk menjadi sebuah industri yang berhasil, maka perlu membangun diri sendiri, dalam hal 
ini yang dimaksud dengan diri sendiri adalah UMKM Kopi 1000 Nurhidayah, agar bisa mandiri secara modal dan penguasaan teknologi hulu - hilir. Selain itu, salah satu pilihan yang baik untuk mengembangkan UMKM Kopi 1000 Nurhidayah adalah bekerjasama dengan para mitra dalam bentuk partnership sehingga semua memiliki hak untuk memajukan UMKM khususnya untuk kopi jantan sendiri. Dengan demikian, UMKM Kopi 1000 Nurhidayah, khususnya produksi kopi jantan Toraja akan semakin maju karena banyaknya pihak yang mendukung serta adanya kemandirian dari petani untuk bisa lebih maju.

e. Harga lebih tinggi dari kopi biasa

Untuk memperoleh biji kopi jantan, agak sulit dan juga memang memiliki kualitas yang baik sehingga mempengaruhi harga yang ditawarkan (harga jual lebih tinggi dibandingkan kopi arabika pada umumnya). Makin sulit untuk mendapatkan suatu barang dengan kualitas yang baik, maka konsumen pun bersedia untuk membayar berapapun harga yang ditawarkan terhadap barang tersebut. Hal ini tentu saja merupakan hal yang baik bagi UMKM Kopi 1000 untuk tetap mempertahankan usaha kopi jantan sehingga mampu memberikan meningkatkan pendapatan petani.

f. Adanya pasar yang tersedia

Pasar untuk kopi jantan boleh dikatakan hanya tertentu saja. Tetapi, karena pasar dari kopi jantan ini tersedia dan memang hanya untuk kalangan tertentu saja, sehingga ini menjadi peluang besar untuk makin memperbaiki kualitas biji kopi yang dihasilkan sehingga bisa menjadi salah satu cara atau taktik promosi bagi pelanggan tetap untuk bisa memperkenalkan kopi jantan tersebut kepada orang orang yang dikenal. Dengan selalu berusaha untuk memberikan yang terbaik untuk konsumen, maka akan memicu konsumen untuk mempromosikan produk yang dihasilkan dan ini bisa membantu promosi kopi jantan toraja yang dihasilkan oleh UMKM Kopi 1000 Nurhidayah secara tidak langsung. Oleh karena itu, perlu untuk mempertahankan atau meningkatkan kualitas produk yang dihasilkan untuk memuaskan pasar. g. Respon konsumen terhadap produk baik Saat mendapatkan respon yang baik daripada konsumen, maka hal ini menjadi peluang besar untuk makin memperluas pasar dan meningkatkan hasil produksi. Respon yang baik salah satunya dapat diketahui dari intensitas para konsumen membeli produk yang dijual, yaitu kopi jantan. Makin merespon baik, makin tinggi minat pembeli terhadap produk yang dihasilkan. Sehingga ini merupakan hal yang baik untuk selalu memberikan kualitas, kuantitas serta harga yang baik bagi konsumen.

h. Pelaku usaha di bidang kopi jantan masih kurang

Pelaku usaha di bidang kopi sudah sangat luas, bahkan di Toraja sendiri hampir semua petani kopi sudah diarahkan untuk menjadi industri yang tidak dikontrol lagi oleh para tengkulak. Hanya saja untuk kopi jantan sendiri, masih sangat kurang yang menjadikan kopi jantan ini sebagai salah satu produk unggulan yang bisa diperjual-belikan. Oleh karena itu, kesempatan ini bisa menjadi peluang besar bagi UMKM Kopi 1000 Nurhidayah untuk memperkenalkan Kopi Jantan Toraja ke pasar yang lebih luas.

Ancaman yang dihadapi oleh UMKM Kopi 1000 Nurhidayah adalah:

a. Regenerasipetanitua-milenial belum dilakukan Salah satu yang dapat mengancam keberlanjutan usaha kopi jantan yang ada di UMKM Kopi 1000 Nurhidayah adalah belum dilakukannya regenerasi petani tua-milenial. Artinya, belum ada generasi muda yang siap untuk menjadi penerus usaha di bidang kopi. Padahal sudah seharusnya para generasi muda yang lebih memiliki semangat dan kreativitas yang lebih dari para orang tua melanjutkan usaha di bidang kopi mengingat peluang usaha di bidang kopi makin meluas dan cukup menjanjikan. Semangat kerja dan kreativitas yang dimiliki oleh para generasi muda tentu saja berbeda dengan para generasi tua. Oleh karena itu perlu adanya pergantian generasi untuk mengembangkan usaha kopi di UMKM Kopi 1000 Nurhidayah agar kreativitas yang dimiliki para generasi muda dapat tersalurkan dengan baik. 
b. Ego area produksi muncul

Yang menjadi salah satu kendala yang dapat mengahambat berjalannya usaha kopi yang ada di UMKM Kopi 1000 Nurhidayah adalah adanya ego area produksi di kalangan petani. Jika ego area produksi muncul, maka kerjasama antar petani pun kurang. Jika kerjasama kurang, maka tujuan yang ingin dicapai bersama tidak akan maksimal sehingga harapan untuk mengembangkan bisnis usaha kopi jantan pun tidak dapat berlanjut. Oleh karena itu, seharusnya para petani bisa menurunkan ego masing-masing sehingga Kerjasama antar petani dapat terbentuk maksimal dan tujuan dapat tercapai secara maksimal.

c. Permintaan masih kurang

Permintaan dianggap masih kurang karena untuk saat ini konsumen kopi jantan Toraja adalah kalangan tertentu saja, sehingga hal ini dianggap sebagai sesuatu yang dapat mengancam keberlanjutan usaha kopi jantan dari segi pemerataan selera konsumen. Oleh karena itu, UMKM Kopi 1000 Nurhidayah perlu untuk memperluas pasar dengan meningkatkan promosi. Semakin luas pasar yang dijangkau maka permintaan terhadap kopi jantan Toraja makin meningkat.

d. Biaya pengiriman dan pengemasan cukup tinggi Jika biaya pengiriman dan pengemasan tinggi, maka hal ini dapat mempengaruhi harga jual produk yang ditawarkan. Semakin tinggi biaya pengiriman dan pengemasan, maka harga jual juga akan semakin tinggi untuk menutupi biaya yang dikeluarkan tidak merugikan. Jika hal ini terus berlanjut, maka UMKM Kopi 1000 Nurhidayah perlu untuk meningkatkan produksi, memperluas pasar agar keuntungan yang diperoleh dapat menutup biaya pengiriman dan pengemasan yang cukup tinggi. Karena jika tidak demikian, maka usaha kopi jantan Toraja ini bisa mengalami kerugian besar terlebih bisa kehilangan konsumen jika harga jual semakin tinggi.

e. Dukungan pemerintah kurang

Selama beberapa tahun berjalannya usaha kopi jantan UMKM Kopi 1000 Nurhidayah ini, para petani dan seluruh stakeholder yang terlibat di dalamnya merasa bahwa keterlibatan pemerintah untuk kemajuan usaha ini masih kurang. Terutama dari segi permodalan dan promosi. Tetapi hal ini juga dipandang baik oleh para stakeholder karena dengan demikian dapat memicu kemandirian petani kopi jantan Toraja sehingga dengan kemandirian yang dimiliki bisa memberikan hasil yang terbaik. Tetapi walau demikian, UMKM Kopi 1000 Nurhidayah harus tetap berusaha untuk mendapatkan dukungan dari pemerintah untuk bisa tetap memperlancar jalannya usaha kopi Jantan Toraja ini. Mendapatkan dukungan yang baik dari pemerintah, dapat memberikan dampak yang positif bagi petani agar leluasa untuk memberikan karya atau hasil terbaik.

f. Munculnya pesaing baru

Saat ini, di beberapa tempat di Toraja sudah memperkenalkan produk kopi jantan juga walau masih dalam jumlah yang sedikit. Keunggulan yang dimiliki oleh UMKM Kopi 1000 Nurhidayah adalah memiliki hak paten untuk memperdagangkan kopi jantan dengan label "Kopi Jantan Toraja". Sehingga, walau pesaing yang muncul banyak, tidak seharusnya mengancam keberlanjutan usaha kopi jantan UMKM Kopi 1000 Nurhidayah, tetapi petani yang ada di UMKM harusnya makin meningkatkan kualitas dan kuantitas produksi agar bisa memberikan yang terbaik bagi konsumen.

\section{MATRIKS INTERNAL - EKSTERNAL}

Matriks internal-eksternal (matriks IE) berdasar pada analisis faktor internal dan eksternal yang digabungkan menjadi satu model sugestif. Matriks IE didasarkan pada dua kriteria, yaitu total pembobotan faktor-faktor internal (IFE) (diletakkan pada sumbu X) dan total pembobotan faktor-faktor eksternal (EFE) pada sumbu Y.

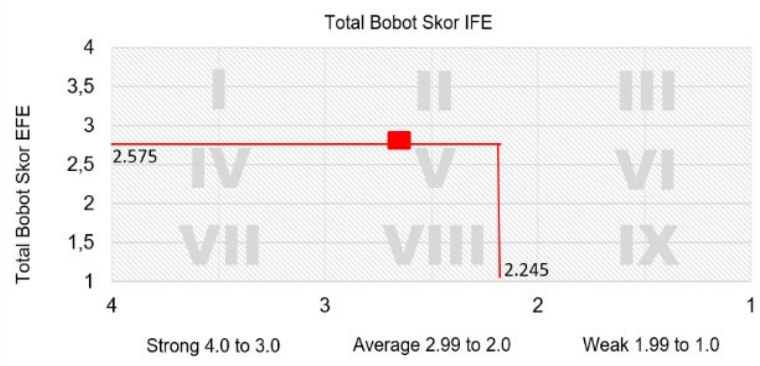

\section{Gambar 1. Matriks Internal - Eksternal UMKM Kopi 1000 Nurhidayah}

Sumber: Data Primer Setelah Diolah, 2020 
Gambar 1 menunjukkan bahwa posisi UMKM Kopi 1000 Nurhidayah berada pada sel V pada matriks IE. Sel tersebut menunjukkan strategi yang sebaiknya dilakukan perusahaan yaitu memelihara dan mempertahankan (hold and maintain). Thana (2017) menuliskan bahwa strategi yang dihasilkan dari matrisk IE hanya menghasilkan alternatif strategi secara umum tanpa adanya implementasi strategi yang lebih teknis pada tingkat perusahaan. Oleh karena itu, UMKM Kopi 1000 Nurhidayah perlu merumuskan strategi untuk menunjang keberhasilan usaha kopi jantan yang diusahakan. Berdasarkan matriks IE, menunjukkan bahwa strategi yang layak digunakan oleh UMKM Kopi 1000 Nurhidayah adalah strategi penetrasi pasar dan pengembangan produk. Strategi penetrasi pasar yang layak untuk dilakukan adalah memperluas pasar melalui promosi dan memaksimalkan pemasaran melalui internet (mengembangkan bisnis e-commerce). Selain itu, untuk pengembangan produk, strategi yang sebaiknya dilakukan adalah memberikan pelatihan-pelatihan untuk meningkatkan SDM petani, (inovasi dan kreativitas petani), sehingga kualitas dan varian biji kopi yang dihasilkan dapat meningkat atau bertambah, serta perlu meningkatkan kerjasama antar-petani agar tujuan dapat dicapai sesuai yang diinginkan.

\section{SIMPULAN DAN SARAN}

\section{SIMPULAN}

1. Faktor internal terdiri dari delapan kekuatan yaitu (a) Kualitas produk baik (lokalita diperkuat budaya), (b) Pelaku utama industri adalah petani langsung, (c) Industri hulu-hilir dan integrasi lokalita, (d) Industri sudah terbentuk di petani, (e) potensi produksi SDM tersedia, (f) Koorporasi petani sudah terbentuk, (g) Lokasi cukup strategis (h) Modal cukup memadai; dan sebelas kelemahan yaitu (a) SDM petani terbatas, (b) Inovasi petani masih kurang bervariasi, (c) Kerjasama petani belum terintegrasi dengan baik, (d) SOP khusus kopi Jantan Toraja belum ditetapkan dan dibuat, (e) Petani masih sangat bergantung pada pendamping, (f) Ketekunan petani belum kuat, (g) Produktivitas kopi rendah, (h) Sarana produksi terbatas, (i) Manajemen produksi belum baik, (j) Promosi kurang, (k) Teknologi dan desain produk masih kurang. Faktor eksternal terdiri dari delapan peluang yaitu (a) Eduagriwosata kopi, (b) Tempat sinergitas semua pelaku usaha kopi, (c) Pemasaran online mendukung, (d) Mandiri modal dan partnership menjadi pilihan, (e) Harga lebih tinggi dari kopi biasa, (f) Adanya pasar yang tersedia, (g) Respon konsumen terhadap produk baik, (h) Pelaku usaha di bidang kopi jantan masih kurang; dan enam ancaman yaitu (a) Regenerasi petani tua-milenial belum dilakukan, (b) Ego area produksi muncul, (c) Permintaan masih kurang, (d) Biaya pengiriman dan pengemasan cukup tinggi, (e) Dukungan pemerintah kurang, dan (f) Munculnya pesaing baru.

2. Matriks IE menunjukkan bahwa usaha kopi jantan UMKM Kopi 1000 Nurhidayah berada pada posisi dimana pihak UMKM harus bertahan (hold and maintain) yang menunjukkan bahwa strategi yang layak digunakan oleh UMKM Kopi 1000 Nurhidayah adalah strategi untuk menjangkau pasar yang lebih luas (penetrasi pasar), yaitu memperluas pasar melalui promosi dan memaksimalkan pemasaran melalui internet (mengembangkan bisnis e-commerce) dan mengembangkan produk, yaitu memberikan pelatihan-pelatihan untuk meningkatkan SDM petani (inovasi dan kreativitas petani) sehingga kualitas dan varian biji kopi yang dihasilkan dapat meningkat atau bertambah, serta perlu meningkatkan kerjasama antar-petani agar tujuan dapat dicapai sesuai yang diinginkan.

\section{SARAN}

Berdasarkan hasil analisis faktor internal dan eksternal, sebaiknya:

1. Pihak UMKM Kopi 1000 Nurhidayah mengupayakan untuk mempertahankan faktorfaktor yang dapat memberikan pengaruh yang baik dan membenahi faktor-faktor yang dapat memberikan dampak yang buruk, khususnya bagi keberlanjutan usaha kopi jantan Toraja.

2. Pihak UMKM Kopi 1000 Nurhidayah menerapkan strategi yang dirancangkan melalui matriks IE agar dapat mencapai tujuan yang diinginkan. 
3. Dilakukan penelitian lanjutan terkait perancangan strategi pemasaran dengan menggunakan alat analisis yang lebih baik, sehingga strategi dapat dirancangkan dengan lebih baik dan spesifik untuk mencapai tujuan yang lebih maksimal.

\section{DAFTAR PUSTAKA}

Audia, Bella., Kaskoyo, Hari., Wulandari, Christine., dan Safe i, Rahmat., 2019. Faktor Internal dan Eksternal dalam Pengembangan Nilai Ekonomi Kopi Codot di HKM Beringin Jaya, Kabupaten Tanggamus. Jurnal Belantara (Vol. 2, No. 2, Agustus 2019). Hal. 142-148. eISSN: 2614-3453 p-ISSN: 2614-7238. DOI: https://doi.org/10.29303/jbl.v2i2.184.

David, F. R. (2011). Strategic Management: Concepts and Cases, Prentice Hall: New Jersey 13th ed, 80 (122), 177-179.

Dien, P., 2012. Kopi Jantan atau Betina. http://primadien.blogspot.com/2012/02/p agi-ada-yang-mau-kopi-jantan-ah-yang.html. Diakses 8 Agustus 2019.

Hetharion, Risye F., Damanik, Inta P. N., Tuhumury, Maisie T.F., 2020. Kemandirian Kelompok Tani Pembibitan Pala Dan Cengkeh di Negeri Lilibooi Kecamatan Leihitu Barat Kabupaten Maluku Tengah. AGRILAN: Jurnal Agribisnis Kepulauan (Volume 8 No. 1 Februari 2020), Hal. 40-51. p-ISSN: 2302-5352 e-ISSN: 2549-7677.

Leliga, Felicia Juliani., Koapaha, Janet Devina., Sulu, Anastasia Cherry., 2019. Analysis of Internal Factor Evaluation Matrix, External Factor Evaluation Matrix, Threats-OpportunitiesWeaknesses-Strengths Matrix, and Quantitative Strategic Planning Matrix on Milk Products and Nutrition Segment of Nestlé India. East African Scholars Journal of Economics, Business and Management, 2 (4):186-191.

Mulyani, Atik., 2019. Analisis Faktor-Faktor yang Mempengaruhi Produktivitas Kopi Robusta terhadap Peningkatan Pendapatan Ekonomi dalam Perspektif Ekonomi Islam (Studi di Perkebunan Kopi Robusta Desa Talang Bandung Bawah Kecamatan Sumber Jaya Kabupaten Lampung Barat) [Skripsi].
Fakultas Ekonomi dan Bisnis Islam, Universitas Islam Negeri Raden Intan Lampung.

Mu'tashim, Mush'ab Ihsan., dan Slamet, Alim Setiawan., 2019. Pengaruh Kualitas Produk dan Kualitas Pelayanan terhadap Kepuasan Konsumen (Studi Kasus Pada Coffee Shop di Kota Bogor). Jurnal Manajemen dan Organisasi (JMO), Vol. 10 No. 2, Agustus 2019, Hal. 118-132. P-ISSN : 2088-9372 E-ISSN : 2527-8991

Nasruddin, Wasrob., Junaidi, Efri., Musyadar, Achmad., dan Dayat., 2015. Tingkat Kewirausahaan Berbagai Pelaku Agribisnis di Wilayah Bogor. Jurnal Agribisnis Indonesia (Vol 3 No 1, Juni 2015); Hal. 55-66. p-ISSN 2354-5690 e-ISSN 2579-3594.

Nasution, Isni Robit., 2019. Pemberdayaan Kelompok Tani dalam Peningkatan Produktivitas Padi Sawah (Oryzae sativa) (Studi Kasus: Kecamatan Lubuk Pakam, Desa Sekip Deli Serdang). Wahana Inovasi (Vol. 8 No.1, Jan - Juni, 2019). e-ISSN: 2614-3003 pISSN: 2089-8592.

Panjaitan, Pardomuan Hotmauli., Hadi, Syaiful., Muwardi, Didi., 2017. Agribisnis Padi Sawah di Kecamatan Medang Deras Kabupaten Batu Bara. JOM Faperta UR Vol. 4 No.1 Februari 2017.

Purnama. (2014). Asean Economy Community (AEC) Bagi Kepentingan Pelaku Usaha Perkebunan Jawa Barat. Diponegoro Journal of Economy, 1(2): 14-37.

Tanan, Aris., Limbongan, Yusuf., Tangkesalu, Joni., 2012. Studi Rantai Niaga Kopi Toraja. Jurnal AgrosainT UKI Toraja Vol. IV No. 1: 435 - 448, Desember 2012 - Maret 2013. ISSN: 20862237.

Thana, D. P., 2017. The Priority of Marketing Strategy of Coffee in Tana Toraja. International Journal of Science and Research (IJSR). ISSN (online): 2319-7064. Hal 953958.

Winata, Sheila Vania., 2016. Perancangan Standard Operating Procedure (SOP) Pada Chocolab. PERFORMA: Jurnal Manajemen dan Start-Up Bisnis (Volume 1, Nomor 1, April 2016). ISSN: 1829-8680 e-ISSN: 2599-0039. 
Yilma, Alemseged dan Kufa, Taye., 2020. Coffee Peaberry as A Potential Seed Source for Production. International Journal of Research Studies in Science, Engineering and Technology, Volume 7, Issue 9, 2020, PP 30 35. ISSN: 2349-476X.

Yulanda, Alivia Chesa., 2019. Analisis FaktorFaktor yang Mempengaruhi Produksi Kopi Arabika (Studi pada Petani Kopi Arabika Kecamatan Bumiaji Kota Batu). Jurnal Ilmiah Mahasiswa FEB (Vol. 7 No. 2, Semester Genap 2018/2019). Universitas Brawijaya. 